Bull. Chem. Soc. Ethiop. 2018, 32(2), 199-211.

ISSN 1011-3924

(c) 2018 Chemical Society of Ethiopia and The Authors

Printed in Ethiopia

DOI: https://dx.doi.org/10.4314/bcse.v32i2.2

\title{
EFFECTIVE FLUORIDE ADSORPTION BY ALUMINUM OXIDE MODIFIED CLAYS: ETHIOPIAN BENTONITE VS COMMERCIAL MONTMORILLONITE
}

\author{
Meseret Dessalegne ${ }^{1}$, Feleke Zewge ${ }^{2}$, Wondafrash Mammo ${ }^{3}$, Girma Woldetinsae ${ }^{3}$ and Isabel \\ Diaz $^{4 *}$ \\ ${ }^{1}$ Ethiopian Institute of Water Resources, Addis Ababa University, P. O. Box 1176, Addis \\ Ababa, Ethiopia \\ ${ }^{2}$ Chemistry Department, Addis Ababa University, P. O. Box 1176, Addis Ababa, Ethiopia \\ ${ }^{3}$ Research and Development Directorate of the Ministry of Mines, Petroleum and Natural Gas, \\ P. O. Box 486, Addis Ababa, Ethiopia \\ ${ }^{4}$ Instituto de Catálisis y Petroleoquímica, CSIC, c/Marie Curie 2, 28049 Madrid, Spain
}

(Received May 22, 2016; Revised March 12, 2018; Accepted May 21, 2018)

\begin{abstract}
This study focuses on the chemical modification of Ethiopian bentonite and commercial montmorillonite with aluminum oxi-hydroxide (AO) for the purpose of defluoridation from aqueous solution. The chemical modification was achieved by preparing AO-modified adsorbents at different $\mathrm{pH}$ values. The adsorbent materials were characterized by X-ray diffraction (XRD), X-ray fluorescence (XRF) and point of zero charge (PZC). From the modified adsorbents, AO-Mont at pH 5 (AO-Mont 5) showed a slight shift of $\mathrm{d}_{001}$ at $2 \theta=7.5^{\circ}$ reflection toward the lower angle $2 \theta=7.0^{\circ}$ as a result of the $\mathrm{Al}_{2} \mathrm{O}_{3}$ insertion into interlayer space. The elemental composition from XRF further showed the increment of Al content accompanied with a decrease in the exchangeable cations in the modified samples and higher content of Al was observed in AO-Mont 5. In addition, the PZC initially 8.5 and 2.5 for raw bentonite and montmorillonite clays were increased to 10 and 8.5 in AO-Bent 5 and AO-Mont 5, respectively. Adsorption of fluoride on these modified adsorbents was studied as a function of preparation $\mathrm{pH}$, contact time, solution $\mathrm{pH}$ and co-existing anions. AO-Mont prepared at $\mathrm{pH}$, which contained higher content of $\mathrm{Al}$ resulted better fluoride removal performance. AO-Bent 5 and AO-Mont 5 have shown five and nine fold increase in fluoride removal capacity, respectively as compared to their respective unmodified clays. The experimental data fitted well with Freundlich adsorption isotherm model which indicated that the surface of the adsorbent is heterogeneous and adsorption of fluoride followed a multilayer sorption. Hence AO-modified Bent and Mont adsorbents prepared at $\mathrm{pH} 5$ can be considered as potential adsorbents for defluoridation from drinking water.
\end{abstract}

KEY WORDS: Defluoridation, Aluminum oxide, Bentonite, Montmorillonite

\section{INTRODUCTION}

Use of groundwater for drinking purpose to urban and rural populations has been practiced for long period of time. However, although groundwater is free from pathogens, its chemical quality can be affected by natural or geogenic contaminants and anthropogenic sources [1]. Fluoride is one of these chemicals which is present in groundwater mainly due to geochemical interactions and climatic conditions [2]. These include granitic basements that contain high fluoride minerals; alkaline volcanic rocks such as East African Rift Valley where high fluoride hyper alkaline volcanic rocks are present and arid climates where groundwater infiltration and flow rates are slow. Low calcium concentration can also lead high fluoride concentration in water [35].

Ingestion of fluoride is beneficial at low concentrations for structural strengthening of tooth enamel and lower the rate of dental caries. However, excessive exposure of fluoride can lead to a number of adverse effects such as dental and skeletal fluorosis [1, 2, 6-8]. Prolonged exposure

*Corresponding author. E-mail: idiaz@icp.csic.es

This work is licensed under the Creative Commons Attribution 4.0 International License 
increases the risk of developing crippling skeletal fluorosis and other non-skeletal effects such as on renal, gastrointestinal and immune systems. It has been estimated more than 200 million people worldwide are at risk of fluorosis [9]. Hence the WHO has set a guideline value for fluoride in drinking water to be $1.5 \mathrm{mg} / \mathrm{L}$ [10]. Nevertheless, this value should be re-considered for hot and arid areas where people have higher daily intake of water. Problems caused by elevated fluoride concentration have been reported in several parts of the world including Ethiopia [11, 12]. Ethiopian Ministry of Water Resources estimated more than 11 million people in Ethiopian Rift Valley rely on fluoride contaminated drinking water [12-14].

Removal of fluoride from water is considered as the primarily option in areas where the access of alternative water source is limited. Several technologies are available for removal of fluoride from drinking water. Depending on the fluoride removal processes involved, these technologies can be classified as adsorption [15-18], precipitation and coagulation [19-21], ion exchange [22, 23] and membrane based methods [24-26]. Among these processes, adsorption is widely used due to availability of wide range of adsorbents, ease of operation, cost effective and high efficiency depending on the nature of adsorbents [5, 27].

Several natural inorganic materials including clays have been used in defluoridation of water [28]. Clays are inexpensive and consequently can be used in less developed countries, especially in rural areas but usually have low effectiveness in removing fluoride $\left(<1 \mathrm{mg} \mathrm{g}^{-1}\right)$ [29-31]. Their fluoride removal capacities can be increased through the process of surface modification, such as loading with multivalent metallic cations $[6,28]$. Several studies reported that aluminum has strong affinity towards fluoride. On the other hand, high cation exchange capacity (CEC) of clays promotes the possibility of modifying their surface by introducing high cationic density species such as $\mathrm{Al}^{3+}$ in exchange of low cationic density species such as $\mathrm{Na}^{+}, \mathrm{Ca}^{2+}, \mathrm{Mg}^{2+}$, and $\mathrm{K}^{+}$ $[1,32]$.

The main Ethiopian Rift Valley and its extension into Afar depression in northeastern Ethiopia host extensive bentonite deposits. The wide spread silicic volcanism and lacustrine environments produce the most favorable sites for accumulation of acid volcanic ash. The alteration of these ashes is the basis for the formation of bentonite [33].

This study aimed at developing good capacity and affordable fluoride removal adsorbent from drinking water using AO modified clays. The clays used are Ethiopian bentonite and commercial montmorillonite for comparison. This study explores the mechanical advantage of these clays as support for $\mathrm{AO}$ and further compares and evaluates their performance to remove fluoride from aqueous solution.

\section{EXPERIMENTAL}

\section{Synthesis}

The bentonite clay used in this study was collected from Afar, Ethiopia. AO-modified clay was prepared at different $\mathrm{pH}$ values using the following procedure. In the first beaker, $10 \mathrm{~g}$ alum $\left(\mathrm{Al}_{2}\left(\mathrm{SO}_{4}\right)_{3} \cdot 14 \mathrm{H}_{2} \mathrm{O}\right)$ was dissolved in $50 \mathrm{~mL}$ of deionized (DI) water. In another beaker $30 \mathrm{~g}$ of clay was added in $450 \mathrm{~mL}$ water. This corresponds to 0.067 moles of $\mathrm{Al}$ in the alum and 0.033 moles of exchangeable cations from the clay $(2: 1)$. This procedure was modified based on our previous work on zeolites [34]. The clay solution was added slowly with continuous stirring to the alum solution. This mixture ( $\mathrm{pH}$ of 3.8) was allowed to age for $24 \mathrm{~h}$ in order to achieve maximum cation exchange between the $\mathrm{Al}^{3+}$ and the cations of the clay, and unreacted aluminum was separated by centrifuging followed by washing with DI water. After separating out the liquid, $200 \mathrm{~mL}$ of DI water was added and the $\mathrm{pH}$ of the resulting mixture was adjusted to 5,7 and 9 by using $2 \mathrm{M} \mathrm{NaOH}$, to precipitate aluminum oxi-hydroxide species. This mixture was allowed to stay for $24 \mathrm{~h}$ with continuous stirring before centrifuging to separate out the liquid. The solid was then washed three times with DI water; centrifuged to separate the liquid and dried to constant weight at $50{ }^{\circ} \mathrm{C}$ for $24 \mathrm{~h}$ in an oven. After conducting quick defluoidation 
tests, AO-montmorillonite prepared at $\mathrm{pH} 5$ (AO-mont 5) showed better results and AObentonite (AO-bent) was prepared at this $\mathrm{pH}(\mathrm{pH} 5)$ following the same procedure.

\section{Characterization}

The X-ray diffraction (XRD) pattern of raw clays (Bent and Mont) and AO-modified Mont at different $\mathrm{pH}$ values (AO-Mont 5, AO-Mont 7 and AO-Mont 9) was recorded by an X-ray diffractometer (X'pert PRO, PANalytica, the Netherlands) using $\mathrm{Cu} \mathrm{K} \alpha$ radiation $(\lambda=0.1542$ $\mathrm{nm}$ ). Elemental composition was determined by X-ray fluorescence spectrometer (SPECTRO XEPOS, USA) in Switzerland. Surface area of the samples was determined by $\mathrm{N}_{2}$ adsorption method (Thermofinnigan Sorptomatic 1900, Germany). Samples were first out gassed at $110{ }^{\circ} \mathrm{C}$ and then allowed to cool to room temperature. The point of zero charge (PZC) was measured by the potentiometric mass titrations technique. PZC was identified as the common intersection point of potentiometric curve of the blank solution with the corresponding curves of the impregnating suspensions containing $0.5,1.0$, and $1.5 \mathrm{~g}$ of adsorbents in electrolytic solution ( $0.03 \mathrm{~N} \mathrm{NaNO}_{3}$ in $50 \mathrm{~mL}$ of deionized water). The experiment was performed under a $\mathrm{N}_{2}$ atmosphere and the aqueous suspensions were equilibrated for $1 \mathrm{~h}$ to reach an equilibrium $\mathrm{pH}$ value. Small amount of $1 \mathrm{M} \mathrm{NaOH}$ was added to make the $\mathrm{pH}$ around 10 and recorded as initial $\mathrm{pH}$ after 15-20 min. Then the solid suspensions were titrated by $0.1 \mathrm{~N} \mathrm{HNO}_{3}$, using 665 Dosimat (Metrohm, Switzerland). The $\mathrm{pH}$ of each suspension is then measured with 1 min time interval using a digital $\mathrm{pH}$ meter.

\section{Defluoridation studies}

Defluoridation study was conducted in batch system. All the tests were carried out in polyethylene test tubes in duplicate at a volume of $50 \mathrm{~mL}$, shaking rate of $200 \mathrm{rpm}$ and at room temperature $\left(22-23{ }^{\circ} \mathrm{C}\right)$. Samples taken were filtered through nylon filters $(0.45 \mu \mathrm{m}$, WICOM, Germany), and analyzed immediately for its fluoride content. The defluoridation capacity and percentage of adsorption under specified conditions were determined based upon the measurement of the liquid phase concentration.

The amount of fluoride adsorbed per unit mass of adsorbent (capacity, $\mathrm{q}_{\mathrm{t}}$ ) and fluoride removal efficiency $(\% \mathrm{R})$ relative to the initial concentration of the system was calculated as:

$q_{t}=\left(\frac{C_{o}-C_{t}}{m}\right) V$

$\% R=\left(\frac{C_{o}-C_{t}}{C_{o}}\right) \times 100$

where $C_{o}$ and $C_{t}$ are fluoride concentrations in solution $(\mathrm{mg} / \mathrm{L})$ initially and at any time $(\mathrm{t})$ respectively, $\mathrm{m}$ is the mass of the adsorbent $(\mathrm{g}), \mathrm{V}$ is the volume $(\mathrm{L})$ of solution. . In Equation (2), $\mathrm{Ct}=\mathrm{Ce}$ (fluoride concentrations remaining in the solution at equilibrium in $\mathrm{mg} / \mathrm{L}$ ), $\mathrm{qt}=\mathrm{qe}$ (equilibrium adsorption capacity in $\mathrm{mg} / \mathrm{g}$ ).

Effect of contact time on AO-modified montmorillonite prepared at $\mathrm{pH} 5$ (AO-Mont 5) and AO-modified bentonite at $\mathrm{pH} 5$ (AO-Bent 5 ) was studied by varying the contact time from ( 5 to $1440 \mathrm{~min}$ ); at dose of $4 \mathrm{~g} / \mathrm{L}$ and initial fluoride concentration of $10 \mathrm{mg} / \mathrm{L}$. Effect of raw water $\mathrm{pH}$ was studied separately for $\mathrm{AO}-\mathrm{Mont} 5$ and $\mathrm{AO}-\mathrm{Bent} 5$. The $\mathrm{pH}$ of raw water was adjusted in the range of (3-11) by using $\mathrm{HCl}$ and $\mathrm{NaOH}$. The experimental conditions were $10 \mathrm{mg} / \mathrm{L}$ initial fluoride concentration, $4 \mathrm{~g} / \mathrm{L}$ adsorbent dose and $3 \mathrm{~h}$ contact time. The effect of other competing anions $\left(\mathrm{Cl}^{-}, \mathrm{NO}_{3}{ }^{-} \mathrm{SO}_{4}{ }^{2-}, \mathrm{HCO}_{3}{ }^{-}\right)$was investigated likewise for both modified adsorbents at concentration of $(0.5-4 \mathrm{mmol} / \mathrm{L})$ by dissolving sodium salts of respective anions. Finally, batch adsorption isotherms were determined under the experimental conditions of $4 \mathrm{~g} / \mathrm{L}$ dose of 
adsorbent; $24 \mathrm{~h}$ contact time and variable initial fluoride concentration in the range of 5-200 $\mathrm{mg} / \mathrm{L}$.

\section{Fluoride analysis}

A fluoride stock solution $(1000 \mathrm{mg} / \mathrm{L}$ ) was prepared from $99.0 \% \mathrm{NaF}$ (BDH Chemicals, England) in DI water. Standard solutions and samples were prepared by appropriate dilution of the stock solution. The fluoride concentration was measured with a $\mathrm{pH} / \mathrm{ISE}$ (ion selective electrode) meter (Orion model, EA 940 Expandable Ion Analyzer, USA) equipped with combination fluoride selective electrode (Orion Model 96-09, USA).

Analysis was performed on equal-volume mixtures of sample and total ionic strength adjustment buffer (TISAB) solution. TISAB was used to suppress interferences and prepared by following recommended procedure [35], except CDTA (trans-1,2-diamineciclohexane-tetracetic acid) was replaced by EDTA.

\section{RESULTS AND DISCUSSION}

\section{Characterization of adsorbents}

XRD patterns of raw Bent, raw Mont and AO-modified Mont (AO-Mont 5, AO-Mont 7, AOMont 9) prepared at varied $\mathrm{pH}$ are shown in Figure 1. The XRD pattern of Mont showed characteristic reflections corresponding to the montmorillonite layered structure at $2 \theta=7.5^{\circ}$ corresponding to the 001 reflection with $\mathrm{d}_{001}=11.77 \AA$ and $2 \theta=18.5^{\circ}$ due to 002 reflection with $\mathrm{d}_{002}=4.79 \AA$ [36-38]. Quartz was also present in the material as shown by reflections responsible at $2 \theta=20.0^{\circ}$ and $26.5^{\circ}$ [38]. The modification process at different $\mathrm{pH}$ yields an optimum result when the AO-modified Mont is prepared at $\mathrm{pH} 5$ (AO-Mont 5). As it can be observed in Figure 1, this sample showed a clear sharpen and shift of the 001 intensity to lower angle $2 \theta=7.0^{\circ}$ indicating the increase of the interlayer d-spacing to $\mathrm{d}_{001}=12.67 \AA$. This could be indicating that at this $\mathrm{pH}$ the modification has resulted in a more efficient insertion of the $\mathrm{Al}_{2} \mathrm{O}_{3}$ species into interlayer space [38].

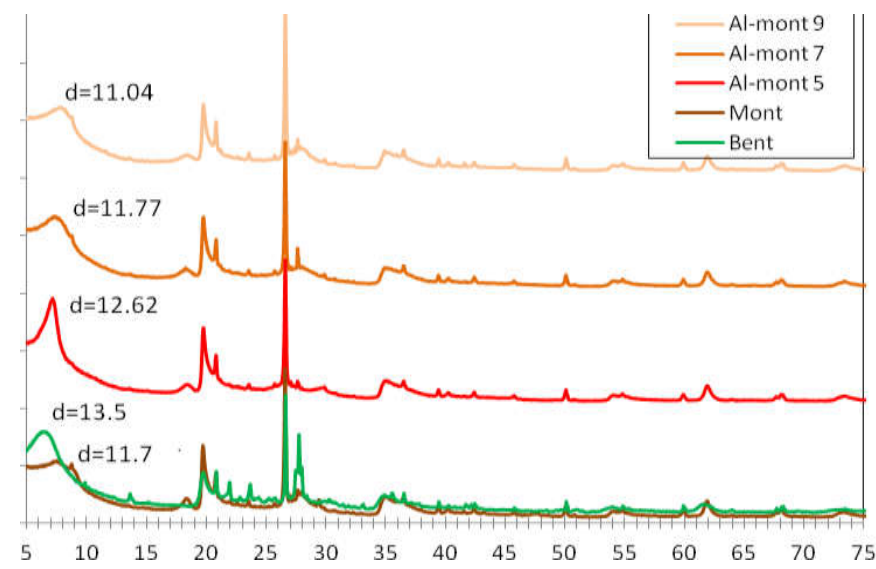

Figure 1. XRD pattern of AO-Mont prepared at varied $\mathrm{pH}$ compared to the raw Mont and raw Bent reflection.

The chemical composition of raw clays and AO-mont modified at different $\mathrm{pH}$ is shown in Table 1. As it is shown from the table, Bent clay is composed largely of Si, Fe and Al. Mont is 
also mainly composed of $\mathrm{Si}$ and $\mathrm{Al}$ but with less $\mathrm{Fe}$ as compared to Bent clay. Other components include $\mathrm{Mg}, \mathrm{Ca}, \mathrm{K}, \mathrm{Na}$ and $\mathrm{S}$. After modification of the Mont clay, the amount of $\mathrm{Al}$ increases to a maximum obtained in AO-Mont 5 modified at $\mathrm{pH}$ 5. Modifications at $\mathrm{pH} 7$ and 9 does not efficiently retain the $\mathrm{Al}$ in the final clay, since the $\mathrm{pH}$ adjustment treatment involves more presence of $\mathrm{Na}$ cations to further exchange with the clay, as it can be observed by the increase of the $\mathrm{Na}$ content while $\mathrm{pH}$ increases. Increased amount of $\mathrm{Al}$ at different $\mathrm{pH}$ accompanied by a decrease in the exchangeable cations $(\mathrm{Ca}, \mathrm{K}, \mathrm{Na})$ in the modified clays indicates the presence of aluminum oxides or substitution (exchange) of $\mathrm{Al}$ for other cations [1]. According to Hofmeister series (lyotrophic series), the relative strength of various cations' adsorption to colloids is $\mathrm{Al}^{3+}>\mathrm{H}^{+}>\mathrm{Ca}^{2+}>\mathrm{Mg}^{2+}>\mathrm{K}^{+}=\mathrm{NH}_{4}^{+}>\mathrm{Na}^{+}$. This could be a good explanation for high concentration of $\mathrm{Al}$ in $\mathrm{AO}-\mathrm{Mont} 5$ as compared with others prepared at neutral $(\mathrm{pH} 7)$ and alkaline $(\mathrm{pH} 9)$ media. Comparison of percentage of elemental composition between the commercial Mont and Ethiopian Bent are shown in Figure 2. The elemental compositions of the two clays were comparable with higher values of $\mathrm{Al}$ and Si measured in Mont while minor impurities of $\mathrm{P}$ and $\mathrm{Cl}$ were observed in the Bent clay.

Table 1. Elemental composition $(\mathrm{mmol} / \mathrm{kg}$ ) of raw Bent, Mont and Al-Mont prepared at different $\mathrm{pH}$ values.

\begin{tabular}{|l|c|c|c|c|c|c|c|c|}
\hline \multirow{2}{*}{ Adsorbents } & \multicolumn{9}{|c|}{ Elemental composition in (mol/kg) } \\
\cline { 2 - 10 } & $\mathrm{Na}$ & $\mathrm{Mg}$ & $\mathrm{Al}$ & $\mathrm{Si}$ & $\mathrm{K}$ & $\mathrm{Ca}$ & $\mathrm{Fe}$ & $\mathrm{S}$ \\
\hline Bent & 0.38 & 0.60 & 2.42 & 8.36 & 0.35 & 0.30 & 1.22 & 0.01 \\
\hline Mont & 0.37 & 0.92 & 2.92 & 9.01 & 0.12 & 0.27 & 0.47 & 0.03 \\
\hline Al-Mont 5 & 0.17 & 0.66 & 3.08 & 8.43 & 0.10 & 0.08 & 0.44 & 0.04 \\
\hline Al-Mont 7 & 0.38 & 0.52 & 3.01 & 8.13 & 0.10 & 0.09 & 0.43 & 0.06 \\
\hline Al-Mont 9 & 0.46 & 0.48 & 2.94 & 8.23 & 0.12 & 0.10 & 0.43 & 0.07 \\
\hline
\end{tabular}

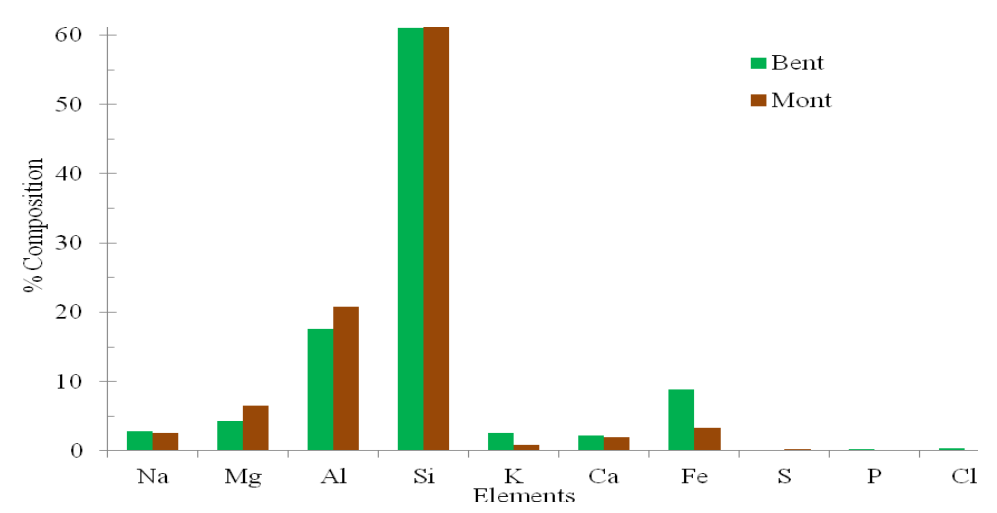

Figure 2. Comparison of $\%$ elemental composition of Ethiopian bentonite and commercial montmorillonite.

The PZC of raw clays and AO modified clays at $\mathrm{pH} 5$; and the surface area are listed on Table 2. It has been reported $\mathrm{pH}_{\mathrm{pzc}}$ of South African bentonite clay to be 8.0 [1] and $\mathrm{pH}_{\mathrm{pzc}}$ for Korean bentonite clay to be 8.0 [39]. The PZC of montmorillonite was 2.5 comparable to other study previously reported [40]. At $\mathrm{pH}<\mathrm{pH}_{\mathrm{pzc}}$, the modified clay surfaces are positively charged, whereas at $\mathrm{pH}>\mathrm{pH}_{\mathrm{pzc}}$, the modified surfaces are negatively charged. Due to the net positive charge of raw and AO-modified clays at $\mathrm{pH}<\mathrm{pH}_{\mathrm{pzc}}$, it attracts fluoride anions. There was an increase in the PZC in the AO-modified clays to 10 and 8.5 in AO-Bent 5 and AO-Mont 5 
respectively which creates extra positive charge on the surface that favors adsorption of fluoride at wider $\mathrm{pH}$ range.

The surface area of the parent clays and one of the modified adsorbents are also collected in Table 1. It can be observed that decreases upon modification in the Mont case, probably due to the increment of the final particle size as a consequence of the AO precipitation.

Table 2. Surface area and point of zero charge for the raw and modified clays.

\begin{tabular}{|l|c|c|c|c|}
\hline Parameter & Bent & Mont & AO-Bent 5 & AO-Mont 5 \\
\hline Surface area $\left(\mathrm{m}^{2} / \mathrm{g}\right)$ & 26.73 & 13.4 & - & 12.5 \\
\hline $\mathrm{pH}_{\mathrm{PZC}}$ & 8.5 & 2.5 & 10 & 8.5 \\
\hline
\end{tabular}

Defluoridation study

Effect of modification $\mathrm{pH}$ on fluoride removal capacity

Comparison on adsorption capacity and efficiency of the raw and AO-modified clays is shown in Figure 3. As it can be seen in the figure, raw clays have very low fluoride adsorption capacity of $(6 \%$ and $5 \%)$. On the other hand, modification of the surface cations with AO has enhanced fluoride removal efficiency to $28 \%$ and $45 \%$ (using AO-bent5 and AO-mont5) respectively. Hence it is believed that the enhanced fluoride removal capacity of the AO modified clays is due to the presence of aluminum oxide (hydroxide) (AO). It is clearly observed from the figure that AO-Mont 5 has high fluoride removal capacity as compared to AO-Mont 7 and AO-Mont 9. This is mainly attributed to the amount of $\mathrm{Al}$ in AO-Mont (3.08 mol Al/kg in Table 1). Since fluoride has high affinity to higher density and stable electropositive species of $\mathrm{Al}^{3+}[1]$, higher fluoride removal capacity of $1.2 \mathrm{mg} / \mathrm{g}$ was observed at $10 \mathrm{mg} / \mathrm{L}$ initial fluoride concentration, 4 $\mathrm{g} / \mathrm{L}$ dose of adsorbent dose and $3 \mathrm{~h}$ contact time. As the result, AO-Mont 5 was chosen for further investigation and AO-bent was also prepared at $\mathrm{pH}$ of 5 (AO-bent 5).

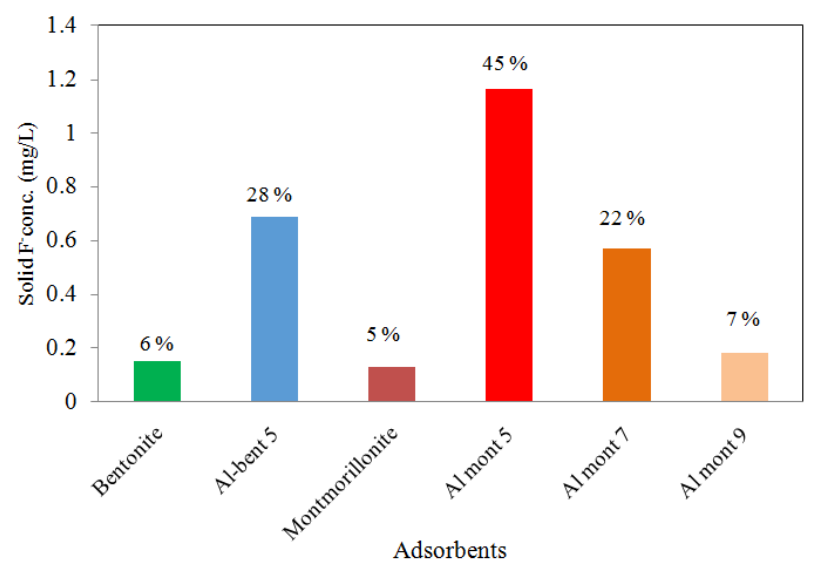

Figure 3. Comparison of fluoride adsorption capacity of raw and AO-modified clays. (At 10 $\mathrm{mg} / \mathrm{L}$ initial $\mathrm{F}^{-}$conc.; $4 \mathrm{~g} / \mathrm{L}$ adsorbent dose and $3 \mathrm{~h}$ contact time.)

\section{Effect of contact time}

The effect of contact time on fluoride removal efficiency of AO-Bent and AO-Mont prepared at $\mathrm{pH} 5$ is shown in Figure 4. It was observed that the fluoride removal gradually increases with 
time and reaches equilibrium $3 \mathrm{~h}$ after which, a slight decrease in the fluoride removal was observed. The increase might be due to the availability of active sites for fluoride sorption and the decrease could be attributed to the ionic interaction of fluoride ion with clay particles. Aggregation of fluoride molecules with increasing contact time prevents further adsorption of fluoride molecules as pores get filled up and start offering resistance to diffusion [41]. Therefore, $3 \mathrm{~h}$ duration was considered as the optimum equilibrium contact time for further adsorption studies.
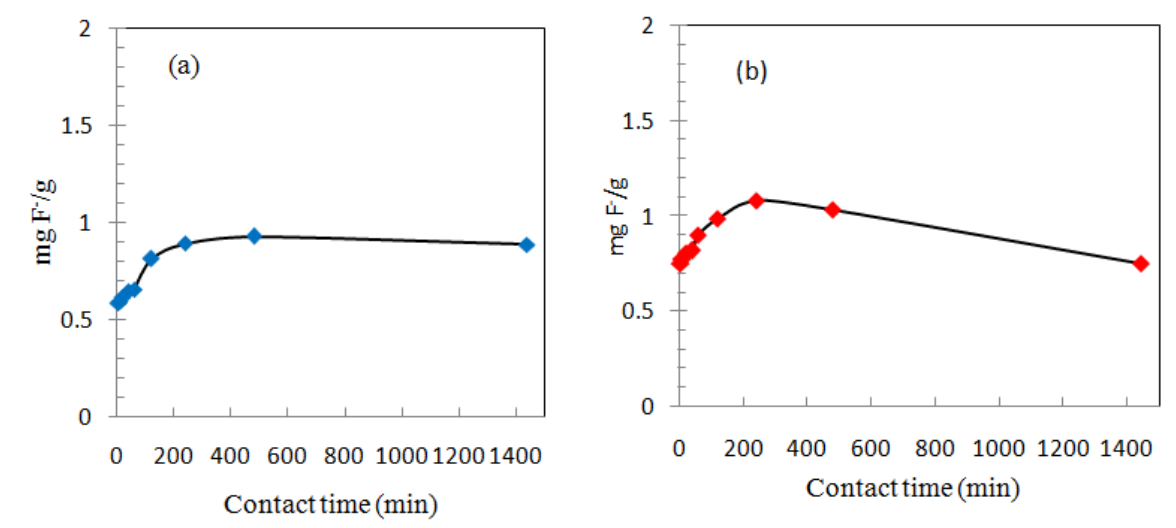

Figure 4. Effect of contact time on fluoride removal capacity (mg F/g) of (a) AO-bent; (b) AOmont (At $10 \mathrm{mg} / \mathrm{L}$ initial $\mathrm{F}^{-}$conc.; $4 \mathrm{~g} / \mathrm{L}$ adsorbent dose and (5-1440 min contact time).
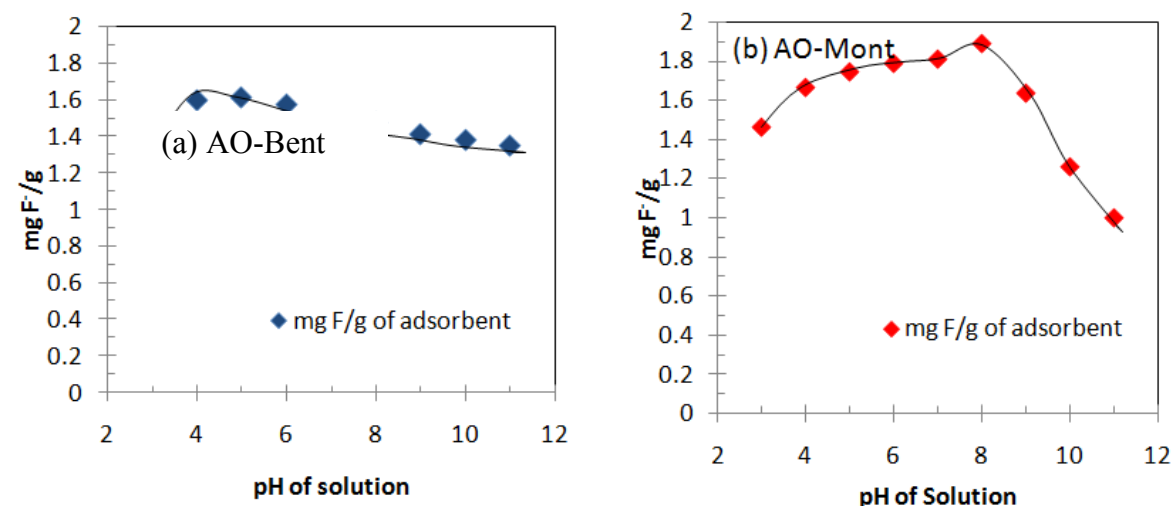

Figure 5. Effect of solution $\mathrm{pH}$ on fluoride removal capacity (a) AO-Bent; (b) AO-Mont (at 10 $\mathrm{mg} / \mathrm{L}$ initial $\mathrm{F}^{-}$conc.; $4 \mathrm{~g} / \mathrm{L}$ adsorbent dose; $3 \mathrm{~h}$ contact time and $\mathrm{pH}(3-11)$ ).

\section{Effect of solution $\mathrm{pH}$}

The $\mathrm{pH}$ of the water to be treated is one of the crucial parameters that can influence the fluoride removal efficiency significantly, and helps in understanding the fluoride uptake mechanism of the adsorbent. The effect of solution $\mathrm{pH}$ on the fluoride removal efficiency of AO-Bent is shown in Figure 5(a) and that of AO-Mont in Figure 5(b). Fluoride removal efficiency of AO-Bent was higher at $\mathrm{pH} 4$ but the change in fluoride adsorption efficiency was less than $10 \%$ over wide range of $\mathrm{pH}$ 3-11. This was also observed by $\mathrm{Mg}$ incorporated bentonite studied earlier [7]. AO-

Bull. Chem. Soc. Ethiop. 2018, 32(2) 
Mont has also shown high fluoride removal efficiency in a wider $\mathrm{pH}$ range of 4-9 where highest removal capacity observed at $\mathrm{pH} 8$. As the $\mathrm{pH}$ increased to 11 , the adsorption capacity was observed to decline to about $40 \%$ which may be due to the abundance of $\mathrm{OH}^{-}$on the adsorbent surface that may affect the fluoride uptake due to extreme competition with $\mathrm{OH}^{-}$.

\section{Effect of other anions}

Figure 6 shows the effect of other anions on the fluoride removal efficiency of AO-Bent and AO-Mont. It was observed that in both AO-modified clays, presence of bicarbonate ion caused significant drop in fluoride removal capacity. This could be due to competition of $\mathrm{HCO}_{3}{ }^{-}$for active sites of adsorbent surface [7]. Other anions $\left(\mathrm{Cl}^{-}, \mathrm{SO}_{4}{ }^{2-}\right.$ and $\left.\mathrm{NO}_{3}{ }^{-}\right)$did not show significant effect at all the concentrations studied on the fluoride removal capacity of AO-Mont. There was a slight effect of $\mathrm{Cl}^{-}, \mathrm{SO}_{4}{ }^{2-}$ and $\mathrm{NO}_{3}^{-}$on fluoride removal capacity of $\mathrm{AO}-\mathrm{Bent}$ in the order of: $\mathrm{HCO}_{3}^{-}>\mathrm{Cl}^{-}>\mathrm{NO}_{3}^{-}>\mathrm{SO}_{4}^{2-}$.
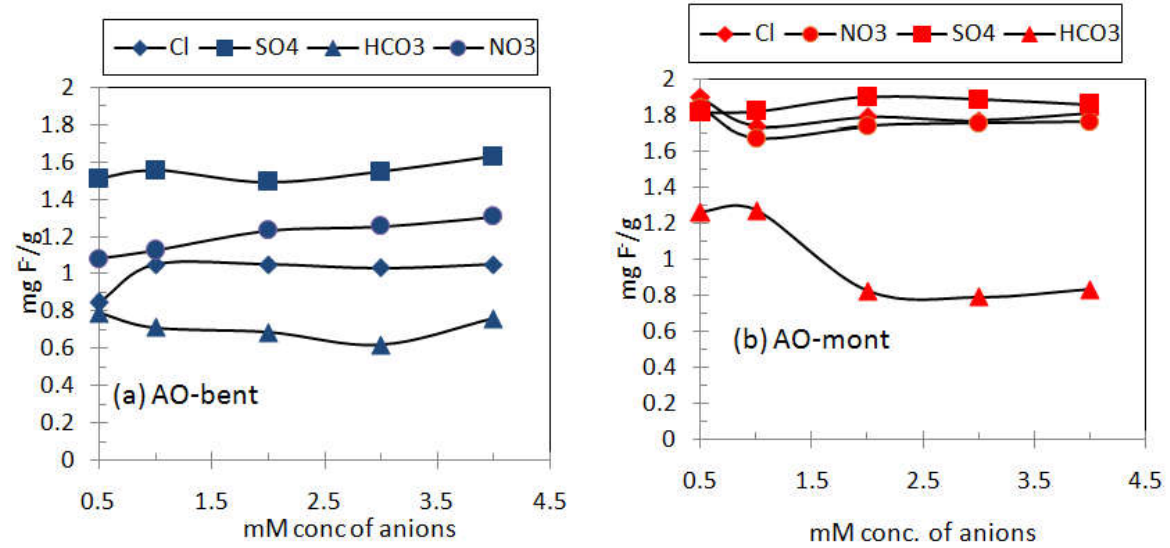

Figure 6. Effect of other anions on fluoride removal capacity of (a) AO-Bent; (b) AO-Mont (At $10 \mathrm{mg} / \mathrm{L}$ Initial $\mathrm{F}^{-}$conc.; $4 \mathrm{~g} / \mathrm{L}$ adsorbent dose; $24 \mathrm{~h}$ contact time and $(0.5-4 \mathrm{mmol} / \mathrm{L})$ other anions).

\section{Adsorption isotherms}

The performance of an adsorbent can be studied by adsorption isotherm data, which can be obtained by a series of experimental tests. Adsorption isotherm plots are shown in Figure 7 and describe that the adsorption capacity increases with increasing equilibrium concentration of fluoride for both AO-Bent and AO-Mont. Modeling the adsorption isotherm data is an essential way for predicting and comparing the adsorption performance, for understanding of the adsorption processes, expression of the adsorbents capacities, and effective design of the adsorption systems. In general, the modeled adsorption isotherm is non-linear curve describing the adsorption phenomenon at a constant temperature and $\mathrm{pH}$. On the other hand, linear analysis of isotherm data into isotherm models is an alternative mathematical approach to predict the overall adsorption behavior.

Linearized plots of Langmuir and Freundlich isotherms are shown in Figure 8. Parameters of these adsorption isotherms fitting for fluoride adsorption data are summarized in Table 3. As it can be seen in Figure 8(a), the correlation coefficient of Langmuir isotherm for AO-Bent and AO-Mont gave a value of $\left(\mathrm{R}^{2}=0.777\right)$ and $\left(\mathrm{R}^{2}=0.869\right)$ respectively. While the correlation coefficient for Freundlich isotherm was $\left(\mathrm{R}^{2}=0.979\right)$ and $\left(\mathrm{R}^{2}=0.998\right)$ respectively. Comparing the regression coefficients $\left(\mathrm{R}^{2}\right)$, the experimental data fitted best with Freundlich isotherm with 
minimum adsorption capacity of $0.142 \mathrm{mg} \mathrm{F}^{-} / \mathrm{g}$ and $0.226 \mathrm{mgF}^{-} / \mathrm{g}$ for AO-Bent and AO-Mont respectively. The correlation observed between the data and Frendlich model in this data range suggested that the surface of the surface of the adsobent is heterogeneous and adsorption of fluoride follows multilayer sorption.
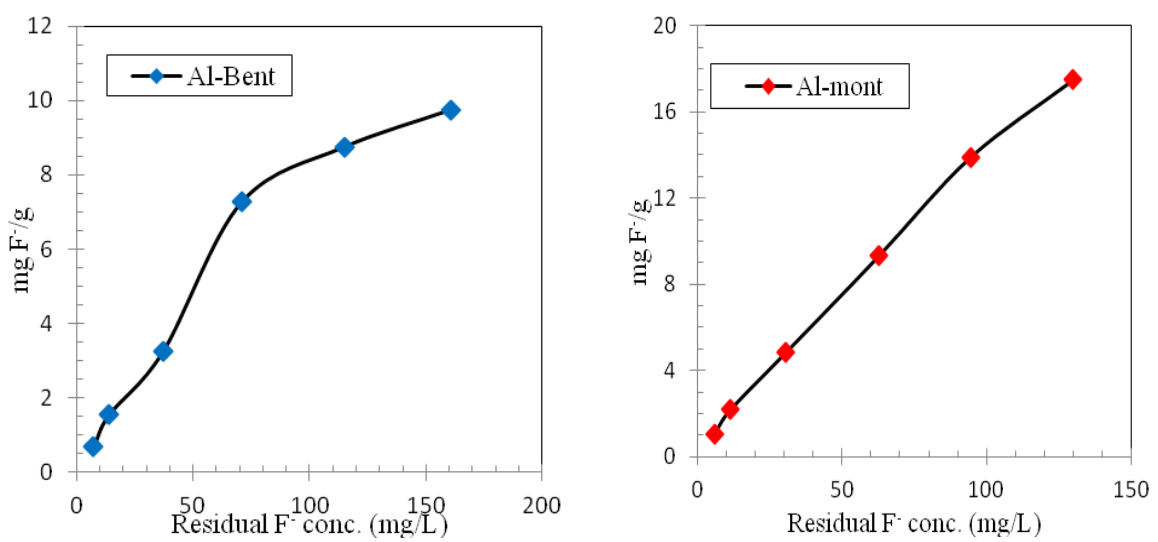

Figure 7. Fluoride adsorption isotherm of (a) Al-bent; (b) Al-mont (5-200 mg/L initial $\mathrm{F}^{-}$conc.; $4 \mathrm{~g} / \mathrm{L}$ adsorbent dose and $24 \mathrm{~h}$ contact time).

Table 3. Summary of linear adsorption isotherm parameters.

\begin{tabular}{|l|l|l|l|}
\hline Isotherm & \multicolumn{3}{|c|}{ AO-Mont } \\
\hline \begin{tabular}{l} 
Langmuir \\
\multicolumn{1}{c|}{$\frac{C_{e}}{q_{e}}=\frac{1}{q_{m} b}+\frac{C_{e}}{q_{m}}$}
\end{tabular} & $\mathrm{q}_{\mathrm{m}}(\mathrm{mg} / \mathrm{g})$ & $\mathrm{b}(\mathrm{L} / \mathrm{mg})$ & $\mathrm{R}^{2}$ \\
\cline { 2 - 4 } & 64.5 & 5.477 & 0.8693 \\
\hline \multirow{2}{*}{$\begin{array}{l}\text { Freundlich } \\
\log q_{e}=\log K_{f}+\frac{1}{n} \log C_{e}\end{array}$} & $\mathrm{~K}_{\mathrm{F}}(\mathrm{mg} / \mathrm{g})$ & $\mathrm{n}$ & $\mathrm{R}^{2}$ \\
\cline { 2 - 4 } & 0.226 & 1.11 & 0.998 \\
\hline Isotherm & \multicolumn{1}{|c|}{ AO-Bent } \\
\hline \multirow{2}{*}{ Langmuir } & $\mathrm{q}_{\mathrm{m}}(\mathrm{mg} / \mathrm{g})$ & $\mathrm{b}(\mathrm{L} / \mathrm{mg})$ & $\mathrm{R}^{2}$ \\
\cline { 2 - 4 } & 24.87 & 8.99 & 0.777 \\
\hline Freundlich & $\mathrm{K}_{\mathrm{F}}(\mathrm{mg} / \mathrm{g})$ & $\mathrm{n}$ & $\mathrm{R}^{2}$ \\
\cline { 2 - 4 } & 0.142 & 1.15 & 0.9787 \\
\hline
\end{tabular}

The removal mechanism using AO-modified clays can be explained as follows:

$$
\begin{aligned}
& =\mathrm{AlOH}+\mathrm{H}^{+} \leftrightarrow \quad=\mathrm{AlOH}_{2}^{+} \\
& =\mathrm{AlOH}_{2}^{+}+\mathrm{F}^{-} \leftrightarrow=\mathrm{AlF}+\mathrm{H}_{2} \mathrm{O}
\end{aligned}
$$

The overall reaction can be:

$=\mathrm{AlOH}+\mathrm{H}^{+}+\mathrm{F}^{-} \leftrightarrow=\mathrm{AlF}+\mathrm{H}_{2} \mathrm{O}$

The first is related to the solution $\mathrm{pH}$ relative to the point of zero charge. At the $\mathrm{pH}$ lower than $\mathrm{PZC}$, i.e. 10 for AO-Bent5 and $8.5 \mathrm{AO}-$ Mont 5, the surface of the adsorbents is positively charged. This favored the electrostatic attraction to fluoride in the aqueous solution. On the other hand, ligand exchange could also be one possible mechanism of fluoride adsorption [8, 4245]. During this process, the hydroxyl group in the adsorbent (when in contact with aqueous solution) is exchanged with fluoride. 

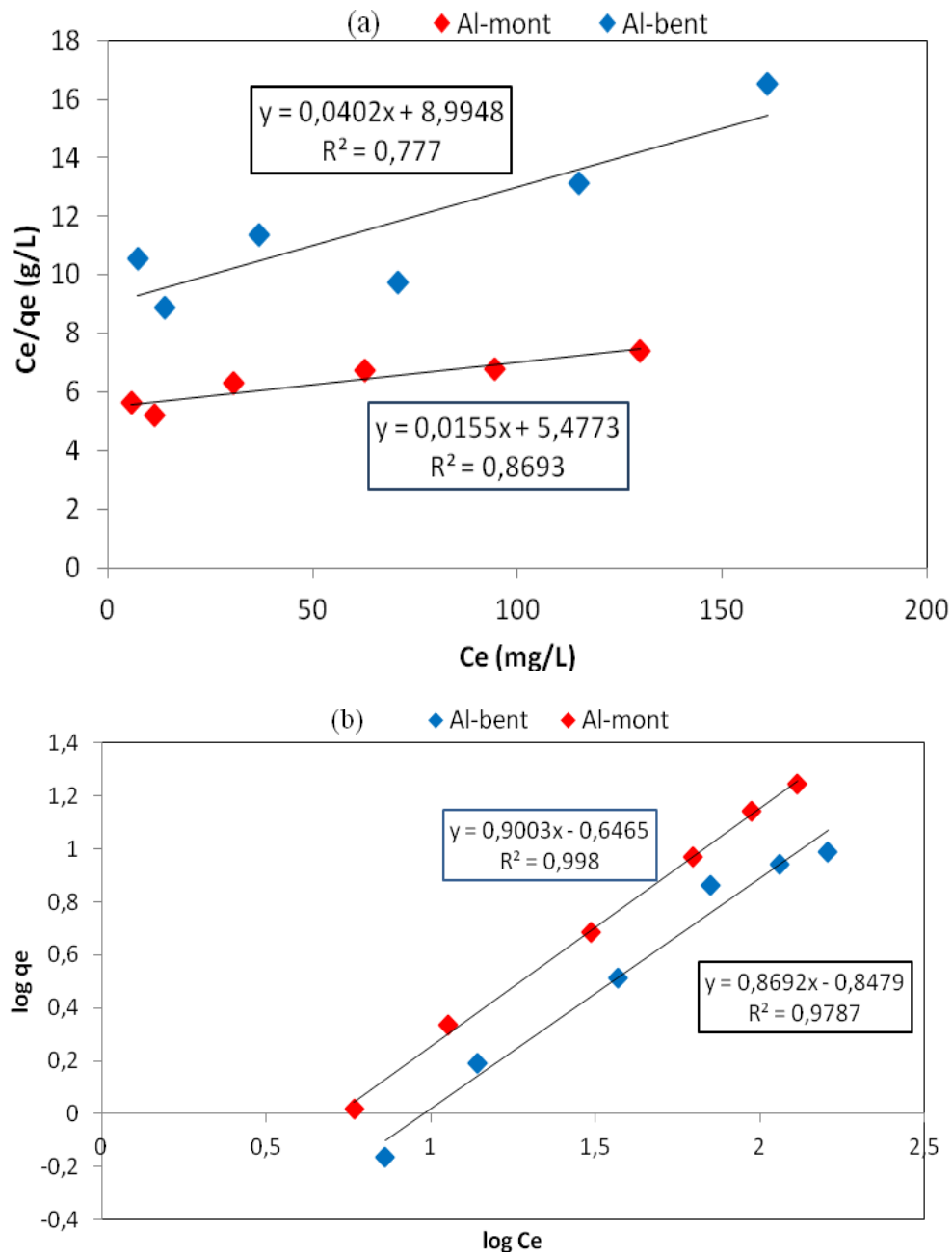

Figure 8. Linear isotherm models for the adsorption of fluoride by AO-bent and AO-mont (a) Langmuir, (b) Freundlich (initial $\mathrm{F}^{-}$conc. (5-200 mg/L); $4 \mathrm{~g} / \mathrm{L}$ adsorbent dose and $24 \mathrm{~h}$ contact time).

\section{CONCLUSIONS}

In this study, chemical modification of Ethiopian bentonite clay and commercial montmorillonite clays with $\mathrm{AO}$ was achieved and resulted in significant enhancement of fluoride removal efficiency. The fluoride removal capacities of raw clays were generally low $0.15 \mathrm{mg} / \mathrm{g}$ and $0.13 \mathrm{mg} / \mathrm{g}$ for bentonite and montmorillonite respectively. AO-modified clay adsorbents were first prepared at different $\mathrm{pH}$ values (5, 7 and 9). AO-Mont 5 was observed to contain high content of Al. This resulted better fluoride removal performance as compared to AO-Mont 7 and AO-Mont 9. AO-Bent 5 and AO-Mont 5 has shown fluoride removal capacity of $0.7 \mathrm{mg} / \mathrm{g}$ and $1.16 \mathrm{mg} / \mathrm{g}$ which means approximately five and nine fold increase in fluoride 
removal capacity respectively as compared to their respective unmodified clays. In addition, AO-modified clays has shown significant removal efficiency over a wider range of $\mathrm{pH}$ (3-11) for AO-Bent and (4-9) for AO-Mont. Bicarbonate ion has shown to have strong competitive effect for fluoride adsorption as compared to other anions studied. The experimental data fitted best with Freundlich adsorption isotherm model which indicated that adsorption of fluoride is chemisorption on the heterogeneous surface of the adsorbent. The low cost and availably of clays makes them very attractive for defluoridation after their modification with AO. Hence AO-modified Bent and Mont adsorbents prepared at $\mathrm{pH} 5$ can be considered as potential adsorbents that could be used for removal of fluoride ions from drinking water.

\section{ACKNOWLEDGMENTS}

The authors would like to acknowledge the National Science Foundation (NSF) and USAID PEER grant [AID-OAA-A-1100012] for financial support. MD acknowledges the Ethiopian Institute of Water Resources, Addis Ababa University and Swiss Federal Institute of Aquatic Science and Technology (Eawag) for financial and technical support.

\section{REFERENCES}

1. Vhahangwele, M.; Mugera, G.W.; Tholiso, N. Defluoridation of drinking water using $\mathrm{Al}^{3+}$ modified bentonite clay: Optimization of fluoride adsorption conditions. Toxicol. Environ. Chem. 2014, 96, 1294-1309.

2. Bhatnagar, A.; Kumar, E.; Sillanpää, M. Fluoride removal from water by adsorption-A review. Chem. Eng. J. 2011, 171, 811-840.

3. Saxena, V.; Ahmed, S. Inferring chemical parameters for the dissolution of fluoride in groundwater. Environ. Geol. 2001, 40, 1084-1087.

4. Eawag Geogenic Contamination Handbook - Addressing Arsenic and Fluoride in Drinking Water, Swiss Federal Institute of Aquatic Science and Technology (Eawag): Dubendorf, Switzerland; 2015.

5. Zhang, S.; Lyu, Y.; Su, X.; Bian, Y.; Yu, B.; Zhang, Y. Removal of fluoride ion from groundwater by adsorption on lanthanum and aluminum loaded clay adsorbent. Envron. Earth Sci. 2016, 72, 299-310.

6. Kamble, S.P.; Dixit, P.; Rayalu, S.S.; Labhsetwar, N.K. Defluoridation of drinking water using chemically modified bentonite clay. Desalination 2009, 249, 687-693.

7. Thakre, D.; Rayalu, S.; Kawade, R.; Meshram, S.; Subrt, J.; Labhsetwar, N. Magnesium incorporated bentonite clay for defluoridation of drinking water. J. Hazard. Mater. 2010, $180,122-130$.

8. Maiti, A.; Basu, J.K.; De, S. Chemical treated laterite as promising fluoride adsorbent for aqueous system and kinetic modeling. Desalination 2011, 265, 28-36.

9. Fewtrell, L.; Smith, S.; Kay, D.; Bartram, J. An attempt to estimate the global burdon of disease due to fluoride in drinking water. J. Water Health 2006, 4, 533-542.

10. WHO Guidelines for Drinking Water Quality, 4th Ed., WHO: Geneva; 2011.

11. Kloos, H.; Tekle-Haimanot, R. Distribution of fluoride and fluorosis in Ethiopia and prospects for control. Trop. Med. Inter. Health 1999, 4, 355-???.

12. Tekle-Haimanot, R. Study of fluoride and fluorosis in Ethiopia with recommendations on appropriate defluoridation technologies. Consultancy Report; 2005.

13. Tekle-Haimanot, R.; Melaku, Z.; Kloos, H.; Reimann, C.; Fantaye, W.; Zerihun, L.; Bjorvatn, K. The geographic distribution of fluoride in surface and groundwater in Ethiopia with an emphasis on the Rift Valley. Sci. Total Environ. 2006, 367, 182-190. 
14. Mulugeta, E.; Zewge, F.; Johnson, C.A.; Chandravanshi, B.S. A high-capacity aluminum hydroxide-based adsorbent for water defluoridation. Desalin. Water Treat. 2014, 525422 5429.

15. Srimurali, M.; Pragathi, A.; Karthikeyan, J. A study on removal of fluorides from drinking water by adsorption onto low-cost materials. Environ. Pollut. 1998, 99, 285-289.

16. Wang, Y.; Reardon, E.J. Activaton and regeneration of a soil sorbent for defluoridation of drinking water. Appl. Geochem. 2001, 16, 531-539.

17. Islam, M.; Patel, R.K. Evaluation of removal effeciency of fluoride from aqueous solution using quick lime. J. Hazard. Mater. 2007, 143, 303-310.

18. Wang, S.-G.; Ma, Y.; Shi, Y.-J.; Gong, W.-X. Defluoridation performance and mechanism of nano-scale aluminum oxide hydroxide in aqueous solution. J. Chem. Technol. Biotechnol. 2009, 84, 1043-1050.

19. Turner, B.D.; Binning, P.; Stipp, S.L.S. Fluoride removal by calcite: evidence for fluorite precipitation and surface adsorption. Environ. Sci. Technol. 2005, 39, 9561-9568.

20. Khatibikamal, V.; Torabian, A.; Janpoor, F.; Hoshyaripour, G. Fluoride removal from industrial wastewater using electrocoagulation and its adsorption kinetics. J. Hazard. Mater. 2010, 179, 276-280.

21. Gong, W.-X.; Qu, J.-H.; Liu, R.-P.; Lan, H.-C. Effect of aluminum fluoride complexation on fluoride removal by coagulation. Colloids Surf. A Physicochem. Eng. Asp. 2012, 395, 88-93.

22. Vaaramaa, K.; Lehto, J. Removal of metals and anions from drinking water by ion exchange. Desalination 2003, 155, 157-170.

23. Meenakshi, S.; Viswanathan, N. Identification of selective ion-exchange resin for fluoride sorption. J. Colloid Interface Sci. 2007, 308, 438-450.

24. Ndiaye, P.I.; Moulin, P.; Dominguez, L.; Millet, J.C.; Charbit, F. Removal of fluoride from electronic industrial effluent by RO membrane separation. Desalination 2005, 173, 25-32.

25. Tahaikt, M.; El Habbani, R.; Ait Haddou, A.; Achary, I.; Amor, Z.; Taky, M.; Alami, A.; Boughriba, A.; Hafsi, M.; Elmidaoui, A. Fluoride removal from groundwater by nanofiltration. Desalination 2007, 212, 46-53.

26. Tahaikt, M.; Ait Haddou, A.; El Habbani, R.; Amor, Z.; Elhannouni, F.; Taky, M.; Kharif, M.; Boughriba, A.; Hafsi, M.; Elmidaoui, A. Comparison of the performances of three commercial membranes in fluoride removal by nanofiltration: Continuous operations. Desalination 2008, 225, 209-219.

27. Mourabet, M.; El Rhilassi, A.; El Boujaady, H.; Bennani-Ziatni, M.; El Hamri, R.; Taitai, A. Removal of fluoride from aqueous solution by adsorption on Apatitic tricalcium phosphate using Box-Behnken design and desirability function. Appl. Surf. Sci. 2012, 258, 4402-4410.

28. Paripurnanda, L.; Saravanamuthu, V.; Jaya, K.; Ravi, N. Defluoridation of drinking water using adsorption processes. J. Hazard. Mater. 2013, 248-249, 1-19.

29. Moges, G.; Zewge, F.; Socher, M. Preliminary investigations on the defluoridation of water using fired clay chips. J. Afr. Earth Sci. 1996, 22, 479-482.

30. Kvalheim, A.; Bjorvatn, K.; Bårdsen, A.; Tekle-Haimanot, R. Significance of elevation on fluoride binding capacity of Ethiopian soils. In Proceedings of $2^{\text {nd }}$ International Workshop on Fluorosis and Defluoridation of Water; Dahi, E.; Nielsen, J.M. (Eds.); International Society of Fluoride Research: Addis Ababa, Ethiopia; 1999.

31. Gomoro, K.; Zewge, F.; Hundhammer, B.; Megersa, N. Fluoride removal by adsorption on thermally treated lateritic soils. Bull. Chem. Soc. Ethiop. 2012, 26, 361-372.

32. Gillman, G.; Sumpter, E. Modification to the compulsive exchange method for measuring exchange characteristics of soil. Soil Research1986, 24, 61-66.

33. Ethiopia, G.S. Mineral Resources of Ethiopia, 2010. Available at: http://www.gse.gov.et/index.php/2016/12/14/occurrence-of-bentonite-in-ethiopia/

34. Dessalegne, M; Zewge, F; Diaz, I. Aluminium hydroxide supported on zeolites for fluoride removal from drinking water. J. Chem. Technol. Biotechnol. 2017, 92, 605-613. 
35. Bailey, P.L. Analysis with Ion-Selective Electrodes, 2nd ed., Hayden: Michigan, USA; 1980.

36. Chávez-García, M.L.; Pablo-Galán, L.; Saucedo-Ramírez, M.P. Synthesis of intercalated Alhydroxy-montmorillonite. J. Mex. Chem. Soc. 2006, 50, 36-41.

37. He, H.; Frost, R.L.; Bostrom, T.; Yuan, P.; Duong, L.; Yang, D.; Xi, Y.; Kloprogge, J.T. Changes in the morphology of organoclays with HDTMA+ surfactant loading. Appl. Clay Sci. 2006, 31, 262-271.

38. Fatimah, I.; Narsito; Wijaya, K. Effect of aluminium content in aluminium pillared montmorillonite on its surface acidity properties. ITB J. Sci. 2011, 43, 123-138.

39. Kim, D.-S. Mesurement of point of zero charge of bentonite by solubilization technique and its dependence of surface potential on pH. Environ. Eng. Res. 2003, 8, 222-227.

40. Karthikeyan, G.; Anitha, P.; Alagumuthu, G. Fluoride adsorption studies of montmorillonite clay. I.J.C.T. 2005, 12, 263-272.

41. Vinati, A., Mahanty, B., Behera, S.K. Clay and clay minerals for fluoride removal from water: A state-of-the-art review. Appl. Clay Sci. 2015, 114, 340-348.

42. Zhu, M.-X.; Xie, M.; Jiang, X. Interaction of fluoride with hydroxyaluminummontmorillonite complexes and implications for fluoride-contaminated acidic soils. Appl. Geochem. 2006, 21, 675-683.

43. Tor, A. Removal of fluoride from an aqueous solution by using montmorillonite. Desalination 2006, 201, 267-276.

44. Ramdani, A.; Taleb, S.; Benghalem, A.; Ghaffour, N. Removal of excess fluoride ions from Saharan brackish water by adsorption on natural materials. Desalination 2010, 250, 408413.

45. Vithanage, M.; Jayarathna, L.; Rajapaksha, A.U.; Dissanayake, C.B.; Bootharaju, M.S.; Pradeep, T. Modeling sorption of fluoride on to iron rich laterite. Colloids Surf. A Physicochem. Eng. Asp. 2012, 398, 69-75. 